Original Research

\title{
Effects of Cold Compress on the Heguous Point of Meridian Large Intestine on Pain before Giving Immunization in Infants
}

\section{Indra Tri Astuti, Kurnia Wijayanti, Laila Nuraini, Nopi Nur Khasanah, and Herry Susanto}

Faculty of Nursing, Sultan Agung Islamic University, Semarang, Indonesia

\begin{abstract}
Introduction: In basic immunizations received by infants $90 \%$ are given by injection. The immunization given by injection is a source of pain which can cause anxiety and trauma not only in infants but also for their families. Thus, it is necessary to deal with the pain with appropriate management. One nonpharmacological therapy that can be used to reduce pain is by providing cold compresses. The aim of this study was to determine the effects of cold compress on the heguous point of meridian large intestine on pain before giving immunization.
\end{abstract}

Methods: This study used the quasi experimental method of posttest design with control group. This study used the instruments of Face, Legs, Activity, Cry and Consolability (FLACC) Behavioral Pain Assessment Scale to measure the pain. The sample was 42 people taken by consecutive sampling. The research data were analyzed by using the Mann Whitney test. The results obtained a p value equal to $0.023(<0.05)$.

Results: This indicates that there were significant differences in pain scores between the two groups, meaning that there is a significant effect of giving cold compresses to the pain score before giving immunization.

Conclusion: This result explains that cold compresses carried out at the heguous point can be used as an alternative for management for nonpharmacological pain in infants during immunization.

\section{ARTICLE HISTORY}

Received: Dec 26, 2019

Accepted: Dec 31, 2019

\section{KEYWORDS}

immunizations; non-pharmacological pain; cold compress; children

\section{CONTACT}

Indra Tri Astuti

$\triangle$ indra@unissula.ac.id

$\doteq$ Faculty of Nursing, Sultan Agung

Islamic University, Semarang,

Indonesia

Cite this as: Astuti, I.T, Wijayanti, K., Nuraini, L., Khasanah, N.N., \& Susanto, H.. (2019). Effects of Cold Compress on the Heguous Point of Meridian Large Intestine on Pain before Giving Immunization in Infants. Jurnal Ners, 14(3si), 358-361. doi:http://dx.doi.org/10.20473/in.v14i3(si).17184

\section{INTRODUCTION}

Immunization is one of the effective ways to prevent disease transmission and is very instrumental in tackling health problems (Hadianti et al., 2014). The importance of immunization is based on the health paradigm which statesthat preventive efforts become the most important thing in improving health status as an effort to achieve the Sustainable Development Goals (SDG) ((IDAI), 2018).

$90 \%$ of basic immunization which is given to infants in their first year of life is carried out by injection. This kind of immunization can also cause a direct reaction such as pain, swelling and rednessat the injection site. Meanwhile, there are also some indirect reactions such as fear, dizziness, and nausea, which make children and parents traumatized to give immunization in the future (Kemenkes RI, 2015). The infancy immunization by injection is the most important source of pain and suffering that can cause anxiety and trauma, not only in children but also in families. Untreated pain can have serious effects, both short-term such as memory of pain, hyper-sensitivity of pain, response to prolonged pain, and long-term pain which includes increased prevalence of neurological deficits, psychosocial problems and resistance to human contact (Wong, Hockenberry, Wilson, Winkelstein, \& Schwartz, 2009). One of the ways to reduce the impact of pain can be done by using non-pharmacological therapy.

Non-pharmacological therapies which can be applied as pain management are arranged in various modalities including physical modalities (physical exercise, massage, vibration, cutaneous stimulation, needling, and so on), cognitive modalities-behavioral (distraction, relaxation, spiritual approaches, and others) and psychotherapy modalities (Wardani, 2014). Pain is reduced when the Acupressure 
Meridian of Large Intestine (LI-4) area between the index finger and thumb is done with an ice compress (Jayaraman \& Jose, 2018). Cold compresses are used to relieve pain by slowing the speed of nerve conduction, causing numbness and working as a counterirritant (Berman, Shirlee, Kozier, Barbara, \& Glenora, 2009).

Based on a preliminary study conducted by researchers using the interview method on September 17, 2018 in Banget Ayu Semarang Public Health Center, the data ofthe immunized babies in the last 3 months were obtained, HB0, DPT, IPV immunization, Polio infants at the age of 0-9 months who were immunized with intra-muscular (IM) accounted for in June at 60 infants, in July at 55 infants, and in August at 52 babies. The coverage of complete immunizationsince the last year in BangetAyu Semarang Health Center has showed the number of HB 0 (100\%), Hepatitis (106\%), BCG (119\%), Polio 1 (112\%), Polio 2 (97\%), DPT 1 (99\% ), DPT 2 (99\%), DPT 3 (101\%), MR (104\%), Measles (106\%). Banget Ayu Semarang Public Health Center at the time of immunization has used warm compresses to reduce the pain of immunization and stated that its effectiveness could reduce the pain caused bythe injection of immunization, but has never used cold compresses before to reduce immunization pain. The parents' response to trauma from the effects of immunization such as fever, crying, fear, and others does not traumatize the parents of infants to giveimmunization for the next time. Thus, it is necessary to deal with the pain with appropriate management. One non-pharmacological therapy that can be used to reduce pain is by providing cold compresses. The aim of this study was to determine the effects of cold compress on the heguous point of meridian large intestine on pain beforegiven immunization.

\section{MATERIALS AND METHODS}

This study is a quantitative study of quasiexperimental research design by using posttest with control group design. Posttest only with control group design is a study that examines an intervention in a group of subjects with a compared group but there is no randomization which is done to put subjects into treatment in control groups (Dharma, 2011).

The respondents in this study were infants who would be immunized intramuscularly (IM) and started from the ages of 0-9 months. This research was conducted from November 2018 to January 2019 with 42 respondents. The intervention was carried out in groups of babies given ice packs (ice cubes wrapped in cotton cloth) on the compressing area on acupressure point Hegu LI-4 which is between the thumb and index finger. The ice compress was given 5 minutes before the immunization, and applied 3 minutes after the immunization for 30 seconds duration, rested for 60 seconds, given an ice pack again for 30 seconds.
The pain measurement instruments cover Face, Legs, Activity, Cry, and Consolability (FLACC) behavior scale and observation sheet (Wong et al., 2009). The data were analyzed by Mann-Whitney statistical test (Dahlan, 2015). This test was chosen because it compares numerical data with abnormal distribution from two groups.

\section{RESULTS}

Table 1 shows the results of the study that the mean age of the control group was $4.33(1,906)$, and the intervention group was $4.05(1,284)$. Table 2 shows the results of the study that the highest sexes were 24 for female (57.1\%).

Table 3 shows the results of the study that the pain score in the control group was 5.00 $(1,673)$ higher than the pain score of the intervention group which was $4.19(1,078)$.

Table 4 is the results of the Mann-Whitney statistical test which shows the $\rho$ value was equal to $0.023(<0.05)$. These results mean that there are significant differences in pain scores in the control group and the intervention group. From the results, it can be concluded that the administration of ice compresses at the Hegu LI-4 acupressure point can reduce pain during immunization in infants aged from 0 to 9 months in Bangetayu Public Health Center.

\section{DISCUSSION}

Judha and Sudarti (2012) stated that pain is an unpleasant sensation which is located at a part of the body. Pain is the body's defense mechanism, existing when there is damaged tissue. This will cause the individual to react by moving the pain stimulus. Pain in children is one thing that can be seen from the emotions and behavior of individuals, subjective, and is a common thing. Pain can also be interpreted as a feeling that is uncomfortable and often experienced by individuals (Andarmoyo, 2013).

The results of the study in Bangetayu Health Center showed that the average pain score was lower in the intervention group accounted for 4.19, compared to the pain score in the control group which showed 5.00. Giving cold compresses can reduce pain and relax muscles by the way of reducing prostaglandin which strengthens the sensitivity of other pain and subcutaneous receptors in the injury site by inhibiting the inflammatory process (Kozzier et al, 2010). The physiological effects of cold therapy can reduce the temperature of the skin and the underlying tissue and cause vasoconstriction. Vasoconstriction decreases blood flow to the affected area and then can reduce oxygen supply and metabolic capacity, as well as the rate of removal of waste substances and cause pale and cold on skin.

The mechanism of giving cold compresses can increase the release of endorphins which block the transmission of pain stimuli and also stimulate nerve fibers that have large Betadiameters, thereby 
Table 1. Frequency Distribution of Respondents Based on the Age

\begin{tabular}{lllll}
\hline Group & Mean & Lowest Age & Highest Age & Standard Deviation \\
\hline Control & 4.33 & 2 & 8 & 1.906 \\
Intervention & 4.05 & 2 & 8 & 1.284
\end{tabular}

Table 2. Frequency distribution of respondents based on the gender

\begin{tabular}{ccc}
\hline Gender & Frequency & Percentage (\%) \\
\hline Male & 18 & 42.9 \\
Female & 24 & 57.1 \\
& 42 & 100
\end{tabular}

Table 3. Frequency distribution of respondents based on the pain score

\begin{tabular}{lllll}
\hline Group & Mean & Lowest Pain Score & Highest Pain Score & Standard Deviation \\
\hline Control & 5.00 & 0 & 7 & 1.673 \\
Intervention & 4.19 & 2 & 6 & 1.078 \\
\hline
\end{tabular}

Table 4. Effect of ice compress test on immunization injection pain score in infants aged from 0 (zero) to 9 (nine) months $(n=42)$

\begin{tabular}{llll}
\hline & $\mathbf{N}$ & $\mathbf{Z}$ & $\mathbf{p ~ v a l u e}$ \\
\hline Control & 21 & -2.270 & .023 \\
intervention & 21 &
\end{tabular}

reducing transmission of pain impulses through small Delta fibers and C nerve fibers (Anugerah, Purwandari, \& Hakam, 2017). Cold compresses using ice slow the conduction of peripheral nerve fibers and reduce the release of inflammatory mediators and nociceptors, thereby causing relatively rapid effects of skin anesthesia (Waterhouse, Liu, \& Wang, 2013). According to (Wong, 2009), cold compresses will cause numbness which is rightly used as a local anesthetic because it can stimulate the skin.

Hegu point LI-4 is chosen because that point is known as the point of pain in the body. The Hegu LI-4 point is also a source point (yuan), the point where Qi is actually radiated in the meridian when stimulated and it will cause energy twice stronger than the other points (Kebudayaan, 2014).

\section{CONCLUSION}

The duty of nurses in the health services to clients is to avoid undesirable things such as trauma, pain, and fear. The conclusions which can be taken from the results of this study show that there are significant effects of ice compresses on injection at the pain scores during immunization in infants aged from 0 to 9 months. Thus, ice compress can be used as an alternative pain management due to its easiness and low cost of use. Bangetayu Health Center can use this study as the basis for the head of Bangetayu Health Center to issue new policy in the matter of reducing the pain of immunization by using an ice pack before the immunization is carried out because ice compresses have proven to be effective to reduce the pain of immunization. For the community, the ice compresses to reduce pain can also be done independently.

\section{REFERENCES}

(IDAI), I. D. A. I. (2018). Seputar pekan imunisasi dunia 2018.

Andarmoyo, S. (2013). Konsep dan proses keperawatan nyeri. Yogyakarta: Arruz Media.

Anugerah, A. P., Purwandari, R., \& Hakam, M. (2017). Pengaruh Terapi Kompres Dingin Terhadap Nyeri Post Operasi ORIF ( Open Reduction Internal Fixation ) pada Pasien Fraktur di RSD Dr . H . Koesnadi Bondowoso Pain in Patients ORIF Fracture in RSD Dr . H . Koesnadi. E-Jurnal Pustaka Kesehatan, 5(2), 247-252.

Berman, A., Shirlee, J. S., Kozier, Barbara, E. R. ., \& Glenora. (2009). Buku ajar praktik keperawatan klinis. Jakarta: EGC.

Dahlan, S. (2015). Statistik untuk kesehatan. Jakarta: Salemba Medika.

Dharma, K. (2011). Metodologi Penelitian. Jakarta: CV. Trans Info Media, Jakarta.

Hadianti, D. N., Mulyati, E., Ratnaningsih, E., Sofiati, F., Saputro, H., Sumastri, H., \& Dkk. (2014). Buku ajar imunisasi. Jakarta: Pusdiknakes Kementrian Kesehatan RI.

Jayaraman, U., \& Jose, J. (2018). Jissy Jose, Umarani J , Effect of ice application in reducing pain perception of toddlers during immunization . 
International journal of recent scientific EFFECT OF ICE APPLICATION IN REDUCING PAIN PERCEPTION OF TODDLERS DURING. 4(May 2013), 3-7.

Judha, M., \& Sudarti, F. A. (2012). Teori pengukuran nyeri dan nyeri persalinan. Yogyakarta: Nuha Medika.

Kebudayaan, D. P. K. dan P. D. J. P. A. U. D. N. dan I. K. P. dan. (2014). Teori Meridian Akupunktur. Jakarta.

Kemenkes RI. (2015). Pengendalian penyakit dan penyehatan lingkungan. Jakarta: Balitbang Kemenkes RI.

Kozzier, B., \& Et, A. (2010). Fundamental keperawatan konsep, proses dan praktik (7 volume 2). Jakarta:
EGC.

Wardani, N. P. (2014). Manajemen Nyeri Akut. 57-69. Waterhouse, M. R., Liu, D. R., \& Wang, V. J. (2013). Cryotherapeutic topical analgesics for pediatric intravenous catheter placement, ice versus vapocoolant spray. Pediatric Emergency Care, 29(1), 8-12.

Wong, D. . (2009). Buku Ajar Keperawatan Pediatric (1st ed.). Jakarta: EGC.

Wong, D. L., Hockenberry, M., Wilson, D., Winkelstein, M. L., \& Schwartz, P. (2009). Buku ajar keperawatan pediatrik (6 volume 2). Jakarta: EGC. 